\title{
Multichronometric Evidence for an In Situ Origin of the Ultrahigh- Pressure Metamorphic Terrane of Dabieshan, China
}

\author{
Valérie Chavagnac, ${ }^{1}$ Bor-ming Jahn, ${ }^{2}$ Igor M. Villa, ${ }^{3}$ \\ Martin J. Whitehouse, ${ }^{4}$ and Dunyi Liu ${ }^{5}$ \\ Géosciences Rennes (UPR 4661-CNRS), Université de Rennes 1, Avenue du \\ Général Leclerc, F-35042 Rennes Cedex, France \\ (e-mail:vmcc@soc.soton.ac.uk)
}

\begin{abstract}
A B S T R A C T
U-Pb zircon data on gneisses indicate a Late Proterozoic protolith at $700 \mathrm{Ma}$ at Bixiling and a Late Archean to Early Proterozoic for the Shuanghe sheet within the ultrahigh-pressure metamorphic terrane of Dabieshan (China). U-Pb zircon and Sm-Nd dates on the gneisses of the Shuanghe sheet constrain a metamorphic peak at $\sim 230 \mathrm{Ma}$. Rb-Sr and ${ }^{40} \mathrm{Ar}-{ }^{39} \mathrm{Ar}$ analyses of phengite from five gneisses in the Bixiling Complex yield ages at 198-212 Ma, overlapping the 190-220-Ma age on eclogites. The host gneisses record a similar metamorphic evolution as the coesite-bearing eclogites since both the peak and the retrograde evolution were contemporaneous. This argues for an in situ tectonic relationship.
\end{abstract}

\section{Introduction}

The Dabie Mountains and the Su-Lu region in central China are known to contain the largest distribution of ultrahigh-pressure metamorphic (UHPM) rocks in the world. They are the eastern end of the 2000-km-long Qinling-Dabie orogenic belt formed during the collision between the Sino-Korean and Yangtze Cratons. The occurrence of coesite and its quartz pseudomorphs in eclogites of continental affinity (Jahn 1998) and metasedimentary rocks implies an ultrahigh-pressure (UHP) metamorphism, hence a subduction of continental fragments to mantle depths. The preservation of UHPM minerals has inspired numerous studies in an attempt to understand the deep subduction of continental crust and the subsequent exhumation of UHPM

Manuscript March 21, 2000; accepted March 8, 2001.

${ }^{1}$ Author for correspondence. Present address: Southampton Oceanography Centre, Challenger Division 674/17, Empress Dock, Southampton SO14 3ZH, United Kingdom. Also affiliated with Universität Bern, Gruppe Isotopengeologie, Erlachstrasse 9a, CH-3012 Bern, Switzerland.

${ }^{2}$ E-mail: jahn@univ-rennes1.fr.

${ }^{3}$ Universität Bern, Gruppe Isotopengeologie, Erlachstrasse 9a, CH-3012 Bern, Switzerland; e-mail: igor@mpi.unibe.ch.

${ }^{4}$ Laboratory for Isotope Geology, Swedish Museum of Natural History, Box 50007, S-104 05 Stockholm, Sweden; e-mail: martin.whitehouse@nrm.se.

${ }^{5}$ Institute of Geology, 26 Baiwanzhuang Road, Beijing 100037 China; e-mail: lui@public.bta.net.cn. rocks. In the Dabie orogen, coesite is observed as inclusions within silicate minerals (e.g., garnet, omphacite, kyanite, and jadeite) and dolomite (Wang et al. 1989; Wang and Liou 1991; Xu et al. 1992; Okay 1993; Cong et al. 1995; Zhang et al. 1995). Furthermore, the preservation of microdiamond within garnet from eclogite, garnet pyroxenite, and jadeitite (Xu et al. 1992) emphasizes the extreme metamorphic conditions. Field observations suggest that coesite-bearing eclogites occur as discontinuous lenses and layers or as boudins within paragneisses or granitic gneisses, which apparently do not contain UHPM assemblages except in a couple of occurrences (Liou et al. 1997). These observations add to the ongoing controversy regarding the exotic/tectonic emplacement or in situ origin of the coesite-bearing metamorphic rocks. Previous combined structural, petrographic, and geochronological studies on UHPM rocks from two main localities (Shima and Wumiao) have suggested an in situ origin of the coesite-bearing eclogites with their associated host gneisses (Rowley et al. 1997; Xue et al. 1997; Hacker et al. 1998). To examine whether such an in situ relationship is more widespread than these two localities, we undertook a detailed and precise geochronological study on other well-known coesite-bearing eclo-

[The Journal of Geology, 2001, volume 109, p. 633-646] @ 2001 by The University of Chicago. All rights reserved. 0022-1376/2001/10905-0006\$01.00 
gites and associated host gneisses from the Bixiling Complex and the Shuanghe UHPM sheet.

In this article, we report new isotopic data using a variety of methods (U-Pb SIMS, Sm-Nd, Rb-Sr, and Ar-Ar) for whole rocks (WR) and minerals (zircon, garnet, phengite, and biotite). These data are used to constrain the metamorphic evolution of the host gneisses and their tectonic relationship with the UHP eclogites.

\section{Geological Setting and Sample Description}

The Qinling-Dabie orogenic belt is situated between the Sino-Korean and Yangtze Cratons (fig. 1a). It has been traditionally considered to be the product of the collision between the two cratons, but the timing of the collision has been controversial. The orogenic belt is composed of an east-west-trending zone of which the Dabieshan represents the eastern most part, and a northeast-southwest-trending zone (Su$\mathrm{Lu}$ region), which has been thought to be the eastern extension of Dabieshan but displaced $\sim 500 \mathrm{~km}$ northward by the Tan-Lu Fault (fig. $1 a_{\text {; }} \mathrm{Xu}$ et al. 1987; Okay and Sengör 1992; Yin and Nie 1993). Coesite and its quartz pseudomorphs are found as inclusions in garnet, omphacite, kyanite, and epidote from eclogites $(<200 \mu \mathrm{m}$; Wang et al. 1989, 1992; Yang and Smith 1989; Okay and Sengör 1993; Zhang et al. 1995), marbles (Wang and Liou 1991, 1993; Xu et al. 1992), and very rarely in gneisses (Enami and Zhang 1990; Hirajima et al. 1990; Wang and Liou 1991; Liou et al. 1997). Eclogites commonly occur as small lenses or blocks $<20 \mathrm{~m}$ in size within serpentinized ultramafics or as thin layers in granitic gneisses or marbles. Massive eclogite bodies occur occasionally; they are best represented by the Bixiling Complex, the largest mafic-ultramafic eclogitic complex in Dabieshan. The UHPM sheet of Shuanghe is of special interest since much of it is of metasedimentary origin, and coesite occurs as small inclusions within jadeite of metasedimentary jadeite quartzite (Cong et al. 1995; Liou et al. 1997).

The Bixiling Complex. The Bixiling Complex (1.5 $\mathrm{km}^{2}$ ) occurs as a metamorphosed layered intrusion enclosed within quartzo-feldspathic gneisses in the eastern part of the Dabie UHPM terrane (fig. 1a, $1 b)$. The eclogites have the typical bimineralic paragenesis of garnet and omphacite, within which coesite occurs as inclusions. Petrological studies on the mafic eclogites and associated garnet-bearing peridotites indicate that the metamorphic evolution followed a clockwise $P T$ loop from peak eclogitic conditions $\left(T=610^{\circ}-700^{\circ} \mathrm{C}_{;} P>27 \mathrm{kbar}\right)$ to albite-epidote (Ab-Ep) amphibolite facies metamorphism $\left(T<600^{\circ} \mathrm{C} ; P<6-15 \mathrm{kbar}\right)$ (Zhang et al.
1995). Geochemical and Sr-Nd isotopic data indicate that the intrusive body was slightly contaminated by the lower crust during emplacement and crystallization (Chavagnac and Jahn 1996). The quartzo-feldspathic gneisses are strongly foliated, but they do not show evidence of UHP metamorphism. They are composed of phengite (Phe), epidote (Ep), biotite (Bt), quartz (Qtz), albite $(\mathrm{Ab})$, titanite (Tit), zircon (Zrn), apatite (Ap), and ilmenite (Ilm). This mineral association corresponds to the Ab-Ep amphibolite facies related to hydration along the retrograde metamorphism (Zhang et al. 1995). However, the destabilization of rutile into ilmenite is indicative of an earlier, higher $P T$ condition.

The Triassic UHP metamorphic age of the Bixiling Complex was established on the basis of seven Sm-Nd garnet-omphacite-WR isochrons between $210 \pm 9$ and $218 \pm 4 \mathrm{Ma}$ (Chavagnac and Jahn 1996), which are close to the 220-230 Ma obtained on U-Pb zircon ages (Ames et al. 1993; Ames 1995; Maruyama et al. 1995; Rowley et al. 1997; Hacker et al. 1998). The primary intrusive age of the Bixiling Complex was constrained by a Sm-Nd garnetonly isochron (7 points, MSWD $=0.7$; Chavagnac and Jahn 1996). The garnet isochron provided an age and an $\epsilon_{i, \mathrm{Nd}}$ value similar to those on garnetomphacite-WR isochrons $(-2.5 \pm 1.1$ and -0.3 to $-1.8 \pm 0.5$, respectively), which highlights the reproducibility and the consistency in the age and suggests that the massif intrusion took place $\sim 300$ m.yr. before the UHPM event. However, no geochronological data have been obtained on the country rocks to examine whether they shared the same metamorphic chronology as the coesite-bearing eclogites. For this purpose, we sampled representative host gneisses, including two Bt-free gneisses (CF 96-21b and CF 96-21c) and three Bt-bearing gneisses (CF 96-21a, CF 96-21d, and BJ 95-08) along the Qianshui River, as shown in figure $1 b$.

The UHPM Sheet of Shuanghe. The second-bestknown, coesite-bearing eclogite locality is situated at Shuanghe, $\sim 25 \mathrm{~km}$ southeast of the Bixiling Complex (fig. 1a). Ultrahigh-pressure rocks are exposed as an elongated thrust sheet within foliated orthogneisses (Cong et al. 1995). The sheet is offset by a dextral strike-slip fault (fig. 1c; Liou et al. 1995). It is composed of layers of massive eclogite, retrogressed eclogite, Ep-two mica schist, garnet- and biotite-bearing gneiss, marble with and without eclogite boudins, jadeite quartzite, and amphibolite. The field association of these lithologies is more or less parallel to the foliation, but it is clearly discordant with respect to the host orthogneisses (outside of the tectonic sheet). The granitic gneisses present a different foliation than the entire UHPM sheet. 


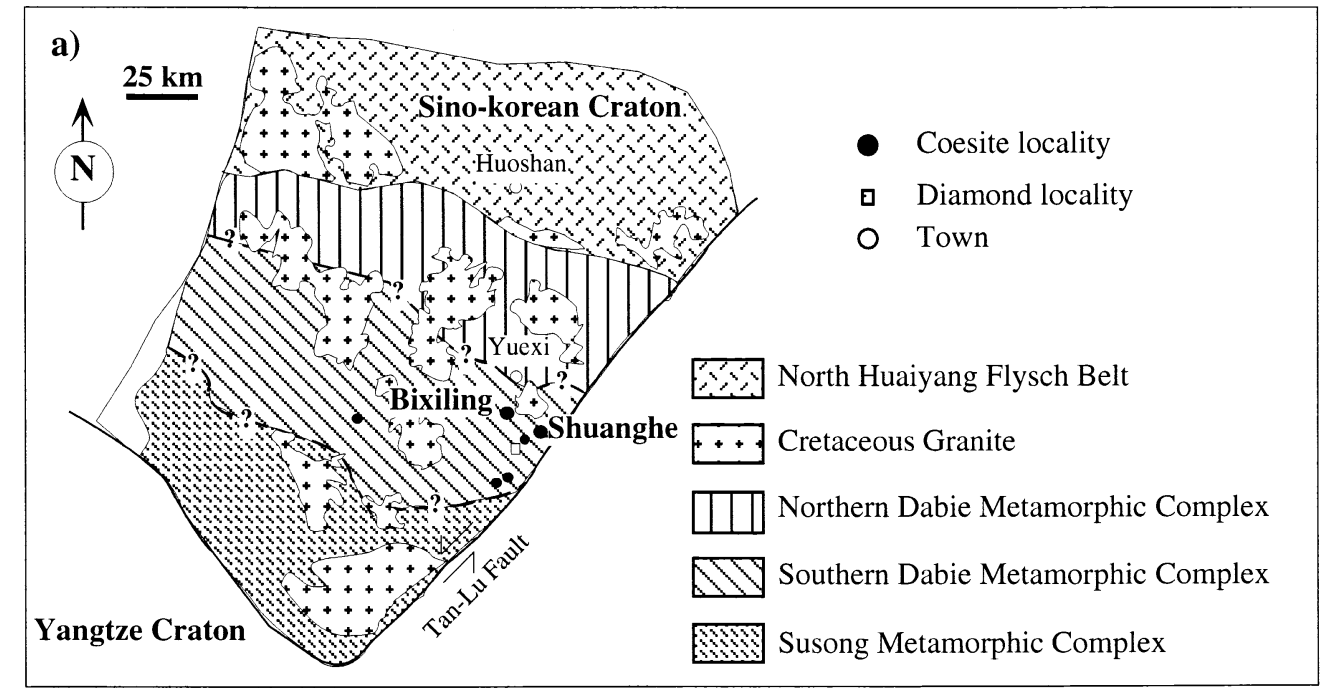

b) The Bixiling Complex

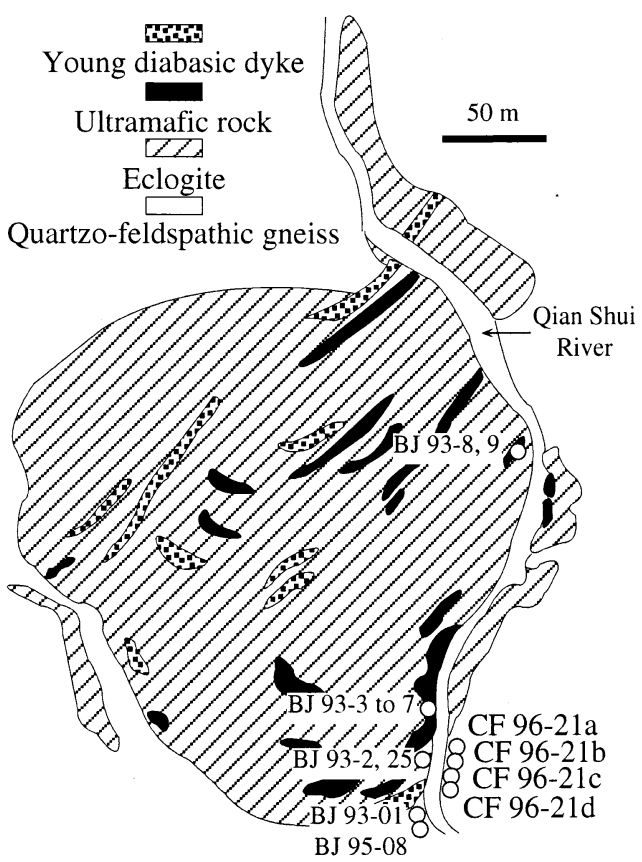

c) The UHPM sheet of Shuanghe

Figure 1. a, General geological map of the Dabie terrane. The tectonic contact between the different units of the Dabieshan are not all well defined and are represented by a dashed line with a question mark. The Bixiling Complex and the ultrahigh-pressure metamorphic (UHPM) sheet of Shuanghe belong to the Southern Dabie Metamorphic Complex, which underwent the highest metamorphic conditions. $b$, Geological sketch of the Bixiling Complex. The sampling area of the gneisses are indicated along with the sampling areas of coesite-bearing eclogites given by Chavagnac and Jahn (1996). c, Sample locations of collected gneisses within the UHPM sheet of Shuanghe.

The particular feature of this UHPM sheet is the occurrence of coesite as inclusions in jadeite quartzite of metasedimentary origin, which thus argues for the subduction of upper crustal material to mantle depths. In addition, the Ep-two mica schist has the mineral association of biotite, phengite, epidote, and quartz with minor amounts of garnet (Grt), kyanite $(\mathrm{Ky})$, Tit, rutile $(\mathrm{Rt})$, amphibole (Amp), and plagioclase (Fs). It is considered to be a retrograde amphibolite facies of quartz eclogite (Cong et al. 1995). Fur- 


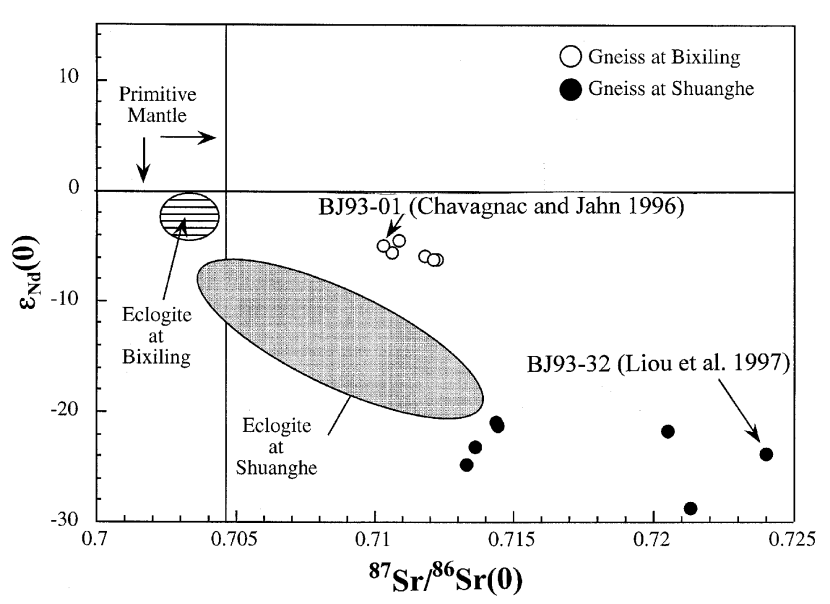

Figure 2. The $\epsilon_{\mathrm{Nd}}(0)$ versus ${ }^{87} \mathrm{Sr} /{ }^{86} \mathrm{Sr}(0)$ diagram for the eclogites and their country rocks from the Bixiling Complex and the Shuanghe sheet. Additional data are from Chavagnac and Jahn (1996), Liou et al. (1997), and Jahn (1998).

thermore, the close field association of Qtz-eclogite, Grt-Bt gneiss, and Ep-two mica schist may indicate a retrograde metamorphic path from the eclogite to amphibolite facies (Cong et al. 1995). Although the tectono-metamorphic evolution has been extensively investigated, age studies have been relatively limited (Cong et al. 1995; Liou et al. 1995, 1997). Li et al. $(1993,2000)$ reported a Sm-Nd Grt-whole-rock age of $229 \pm 3$ and $226 \pm 2 \mathrm{Ma}$ for a Grt-Bt gneiss and $226 \pm 3 \mathrm{Ma}$ for coesite-bearing eclogite interpreted as the timing of the UHPM event. Rb-Sr GrtPhe age from a two-mica gneiss yields an age at $219 \pm 7 \mathrm{Ma}$, which overlaps previous dates on coesite-bearing eclogites (Li et al. 2000). To examine further the tectonic relationship between the eclogites and country gneisses, we chose three Ep-two mica schists (CF 96-36, CF 96-37, and CF 96-38) and one Grt-Bt gneiss (CF 96-39) for a detailed geochronological study (fig. 1c).

\section{Results}

Whole-Rock Isotopic Data. The Rb-Sr and Sm-Nd isotopic data for the granitic gneisses at the Bixiling Complex and the Shuanghe sheet are given in table 1 (tables 1-3 are available from The Journal of Geology's Data Depository free of charge upon request). The Bt-free and Bt-bearing gneisses at the Bixiling Complex are characterized by ${ }^{87} \mathrm{Sr} /{ }^{86} \mathrm{Sr}$ isotopic compositions between 0.710332 and 0.712263 (fig. 2), slightly negative $\epsilon_{\mathrm{Nd}}(0)$ values of -4.3 to -3.5 , and $\mathrm{Nd}$ model ages $\left(T_{\mathrm{DM}}\right)$ ranging from 1.35 to $1.54 \mathrm{Ga}$.
These results indicate Late Proterozoic formation. In contrast, the Shuanghe gneisses represent older rocks as indicated by low $\epsilon_{\mathrm{Nd}}(0)$ values of -21 to -28 , old $T_{\mathrm{DM}}$ ages of $2-3 \mathrm{Ga}$, and high ${ }^{87} \mathrm{Sr} /{ }^{86} \mathrm{Sr}$ isotopic compositions (0.713618-0.721318) (fig. 2; table 1).

U-Pb SIMS Zircon Data. Zircon fractions were separated from a Bt-bearing gneiss of Bixiling (CF 96-21a) and a Grt-Bt gneiss of Shuanghe (CF 96-39). They were analyzed for U-Pb isotopes with a secondary ion microprobe spectrometer (CAMECA IMS-1270) at Stockholm, and the results are reported in table 2 . All zircons present a complicated internal structure with several overgrowths around a rounded to subeuhedral core. U-Pb analyses on zircon CF 96-21a yielded data suggesting a protolith age of $\sim 700 \mathrm{Ma}$. No definite result may be reached due to the large errors vis-à-vis the nearly straight concordia for the age range concerned (fig. $3 a$ ). In contrast, all zircons from sample CF 96-39 yielded discordant data points (fig. $3 b, 3 c$ ), which suggests a complex zircon history. The best regression line gave an upper intercept at $2458 \pm 76 \mathrm{Ma}$ and a lower intercept at $233 \pm 21 \mathrm{Ma}$ (fig. 3b, 3c).

Sm-Nd Isotope Data. One Grt and one Ky fraction were separated from Shuanghe gneiss sample CF 96-39 for Sm-Nd analyses, and the results are given in table 1. A Grt-Ky-WR isochron gave an age of $231 \pm 35 \mathrm{Ma}$ (MSWD $=2.89$ ) with an $\epsilon_{i, \mathrm{Nd}}(t)$ of -18.2 (fig. 4; Grt-Ky Sm-Nd isochron gave $229 \pm$ $4 \mathrm{Ma}$ and Grt-WR gave $238 \pm 4 \mathrm{Ma}$ ). This age is in agreement with our U-Pb SIMS zircon ages (see above) and published Sm-Nd age data on high-pressure metamorphic gneiss (Li et al. 1993, 2000).

$\boldsymbol{R} \boldsymbol{b}$-Sr Isotope Data. Bt and/or Phe, Ap, and Ep were separated from the host gneisses of the Bixiling Complex for $\mathrm{Rb}-\mathrm{Sr}$ analyses. The results are given in table 1. The two Bt-free gneisses (CF 96-21b, CF 96-21c) give identical Phe-Ap-Ep-WR isochron ages at $198 \pm 5 \mathrm{Ma}$, whereas the three Bt-bearing gneisses yield a small range of Phe-Ap-Ep-WR ages from $194 \pm 4$ to $197 \pm 4 \mathrm{Ma}$ (MSWD = 0.28-0.03; fig. 5). Younger $\mathrm{Rb}-\mathrm{Sr}$ ages are obtained by three Bt-WR isochrons between $170 \pm 3$ and $187 \pm 4 \mathrm{Ma}$ (fig. $5 a$, $5 d, 5 e)$.

Ar-Ar Isotope Data. For the country rocks of the Bixiling Complex, 5-10 mg of Phe and Bt separates were used for Ar-Ar isotope analyses (table 3). Electron microprobe analyses were performed on Phe to decipher whether the retrograde metamorphism had influenced the mineral chemical composition. The celadonite content of the dated Phe defines a linear trend corresponding to the Tschermak's exchange $(\mathrm{Fe}, \mathrm{Mg}, \mathrm{Mn}) \mathrm{Si}=\mathrm{Al}^{\mathrm{IV}} \mathrm{Al}{ }^{\mathrm{VI}}$ (fig. $\left.6 a\right)$. The ordinate values are highly variable $3.71-3.96$, which corresponds to Si contents of 3.21-3.41 atoms per formula 

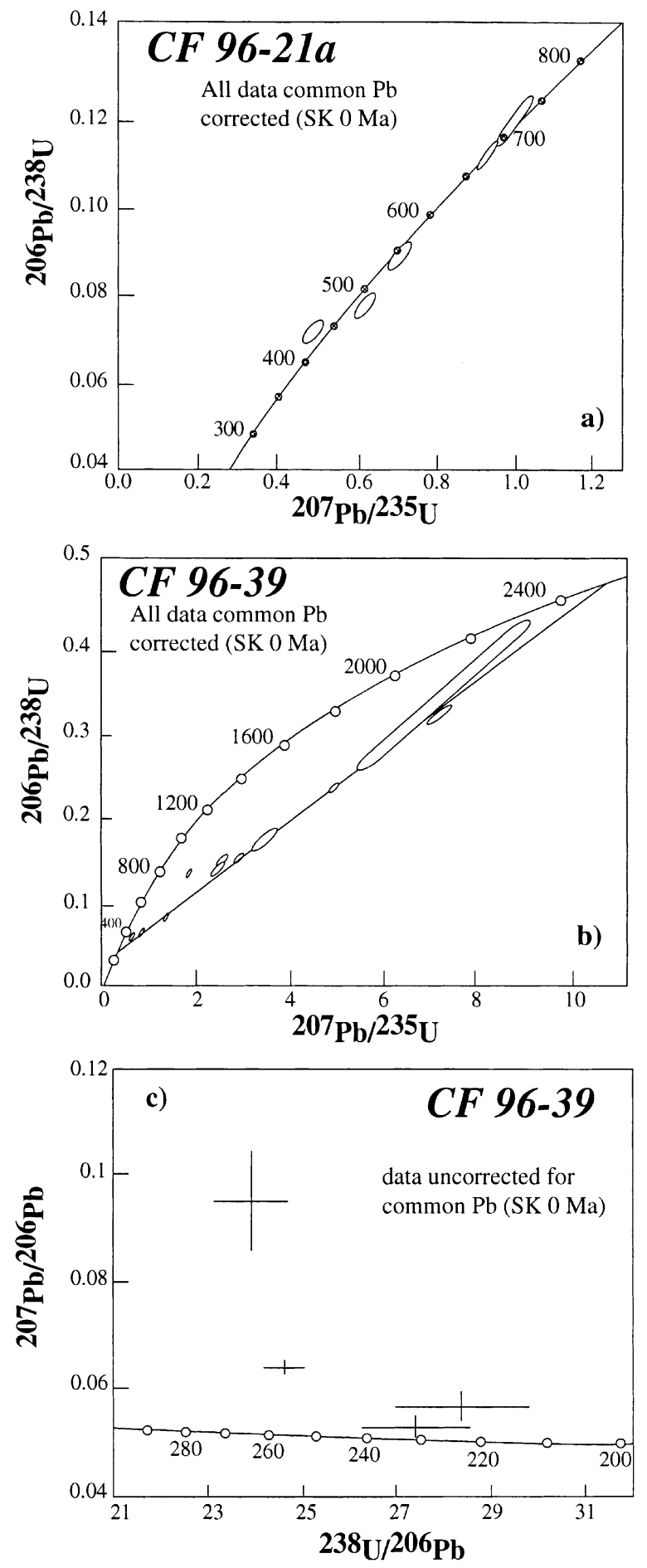

Figure 3. $a, \mathrm{U}-\mathrm{Pb}$ data on $\mathrm{CF} 96-21$ a zircon plot on or close to the concordia diagram. $b$, All data points from sample CF 96-39 are discordant in the concordia diagram. The regression line suggests an upper intercept at $\sim 2.5$ $\mathrm{Ga}$ and a lower intercept at $\sim 230 \mathrm{Ma}$. The suspected age of $230 \mathrm{Ma}$ is confirmed by the Tera-Wasserburg diagram in $c$. unit [a.p.f.u.]) within single phengite grains in all samples. In the $X_{\mathrm{Mg}}$ versus Si diagram (fig. $6 b$ ), we observe (1) a linear trend where Si content increases with $X_{\mathrm{Mg}}$ (2) higher $X_{\mathrm{Mg}}$ values for Phe of Bt-free gneisses than for Phe of Bt-bearing gneisses, and (3) preservation of high $\mathrm{Si}$ values within some Phe grain. This is conclusive evidence of a very pervasive recrystallization at the subgrain scale. The age spectra on Phe from Bt-bearing gneisses (CF 96-21a, CF 9621d, and BJ 95-08) and Bt-free gneisses (CF 96-21b and CF 96-21c) are reported in figure 7. The lowand high-temperature steps are characterized by variable $\mathrm{Ca} / \mathrm{K}$ ratios and correspond to minor gas release (below 5\%; table 3; fig. 8). This encourages us to identify them as contributed by minute impurity phases. The other steps for the two Phe fractions on Bt-bearing gneisses show constant $\mathrm{Cl} / \mathrm{K}$ ratios $(\sim 0.0005)$; these isochemical steps define "plateau ages" of $212 \pm 2$ and $211 \pm 2 \mathrm{Ma}$. In the Bt-free gneisses, the isochemical steps $(\mathrm{Cl} / \mathrm{K}$ around 0.0006$)$ of the three Phe fractions define nearly flat age spectra oscillating within a narrow range between 204 and $209 \mathrm{Ma}$ (fig. 7).

All Phe Ar-Ar ages are older than the corresponding $\mathrm{Rb}$-Sr Phe-Ap-Ep-WR isochron ages. This is understandable since the Ap-Ep association indicates the amphibolite facies retrogression and is not expected to define an isochron dating the formation of the eclogitic paragenesis. The age spectra on $\mathrm{Bt}$ (CF 96-21a, CF 96-21d, and BJ 95-08) are shown in figure 7. They are hump shaped, and the step ages range between 190 and $210 \mathrm{Ma}$. Like Phe, the Bt samples present highly variable $\mathrm{Ca} / \mathrm{K}$ ratios $(0.01-0.5)$ but constant $\mathrm{Cl} / \mathrm{K}$ ratios $(\sim 0.003$ for $\mathrm{BJ} 95-08$ and $\mathrm{CF} 96-$ 21a, 0.007 for CF 96-21d), which are not systematically related to older step ages. Most importantly, the stoichiometry of the analyzed Bt strongly sug-

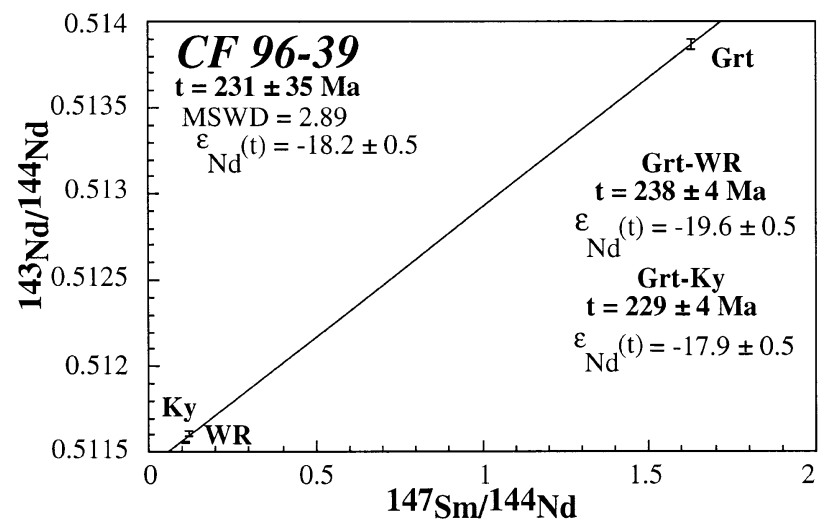

Figure 4. Sm-Nd Grt-Ky whole-rock isochron on sample CF 96-39 gives an age of $231 \pm 35 \mathrm{Ma}(\mathrm{MSWD}=2.89)$. 

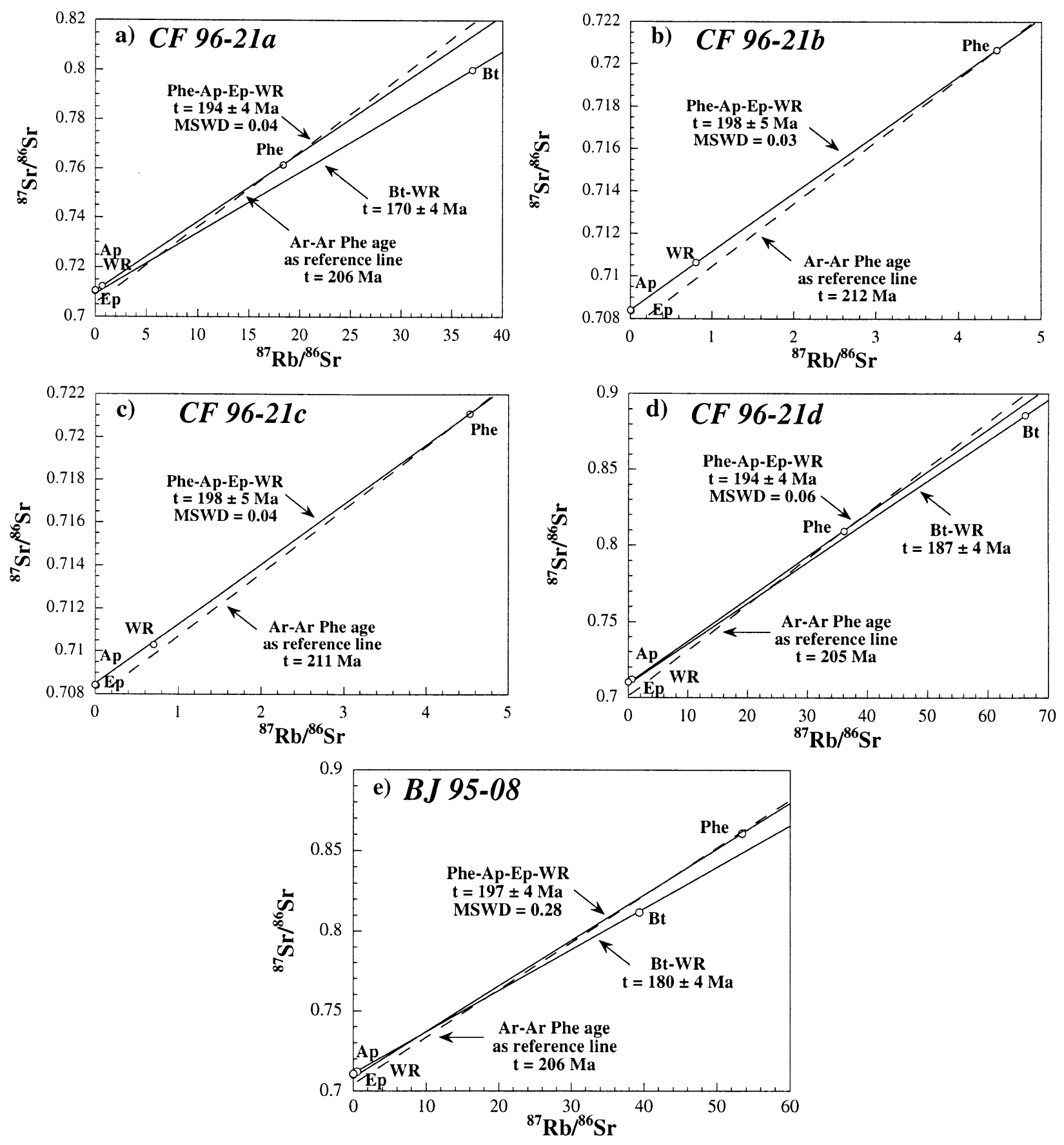

Figure 5. Rb-Sr mineral isochrons for Bt-bearing gneisses $(a, d, e)$ and Bt-free gneisses $(b, c)$. The Ar-Ar phengite age as a reference line is indicated by the dashed line.

gests extensive chloritization, and thus the hump shape of the age spectra likely reflects the mixture with an alteration phase. In addition, all the Bt ArAr ages are significantly older than the respective $\mathrm{Rb}$-Sr Bt-WR two-point ages. Given the evidence for retrogressive recrystallization under hydrating conditions, the WR point may not represent a single, well-defined metamorphic paragenesis, and the BtWR tie line may, therefore, have an ambiguous significance. 

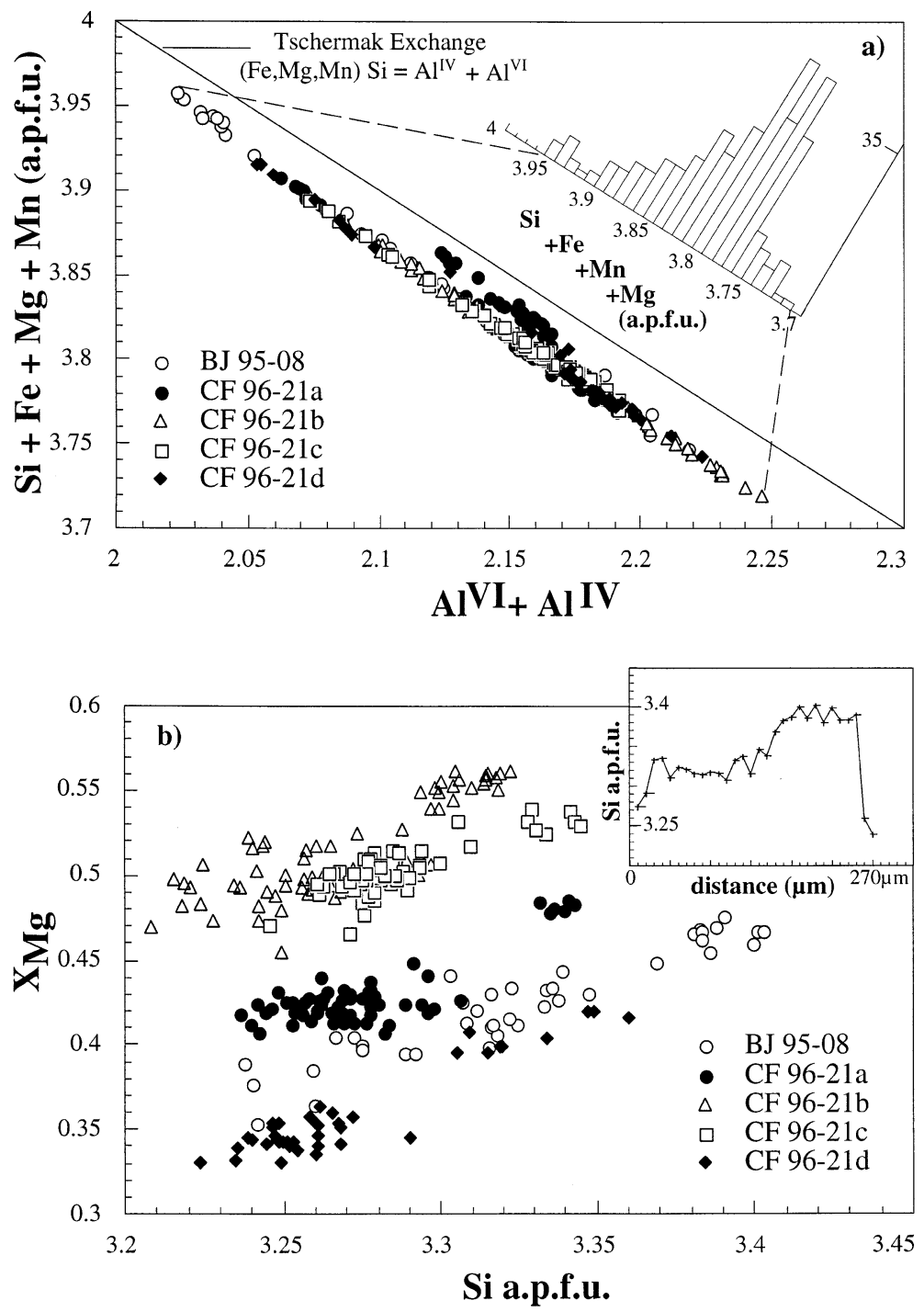

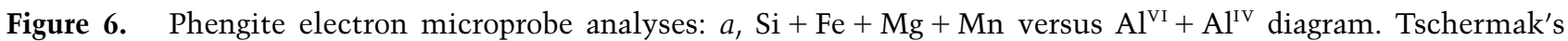
substitution is shown by arrow. $b, X_{\mathrm{Mg}}$ versus Si diagram. The older, high-pressure phengite generation is characterized by higher Si than the later amphibolite facies overgrowths/replacements. The insert shows the variation of Si a.p.f.u. content along a cross section through one Phe grain (BJ 95-08).

\section{Discussion}

Ages of Protolith and Metamorphism. Our U-Pb SIMS zircon data on sample CF 96-21a indicate that the eclogite host gneiss at the Bixiling Complex has a Late Proterozoic emplacement age (fig. 3a). This age is in agreement with the U-Pb concordia upper intercept ages of 700-800 Ma previously obtained on zircons from gneisses (Ames et al. 1993; Rowley et al. 1997; Xue et al. 1997; Hacker et al. 1998). The $\mathrm{Th} / \mathrm{U}$ ratios of gneiss zircon on either core or rim fall within the $1.0 \pm 0.4$ range, which is identical within error to the observed $\mathrm{Th} / \mathrm{U}$ ratios in the zircon cores analyzed by Rowley et al. (1997), which implies that they have an igneous origin. In contrast, the Bixiling gneisses have much older $T_{\mathrm{DM}}$ ages, which range from 1.35 to $1.54 \mathrm{Ga}$ (table 1 ) and $\epsilon_{i, \mathrm{Nd}}(220 \mathrm{Ma})$ of -5 (fig. 2). The coesite-bearing eclogites of the Bixiling Complex (a layered intrusion) were probably emplaced much later in the early Paleozoic or the latest Proterozoic /Chavagnac and Jahn 1996). We may conclude from the Sm-Nd isotopic and geochemical features that the gneisses 


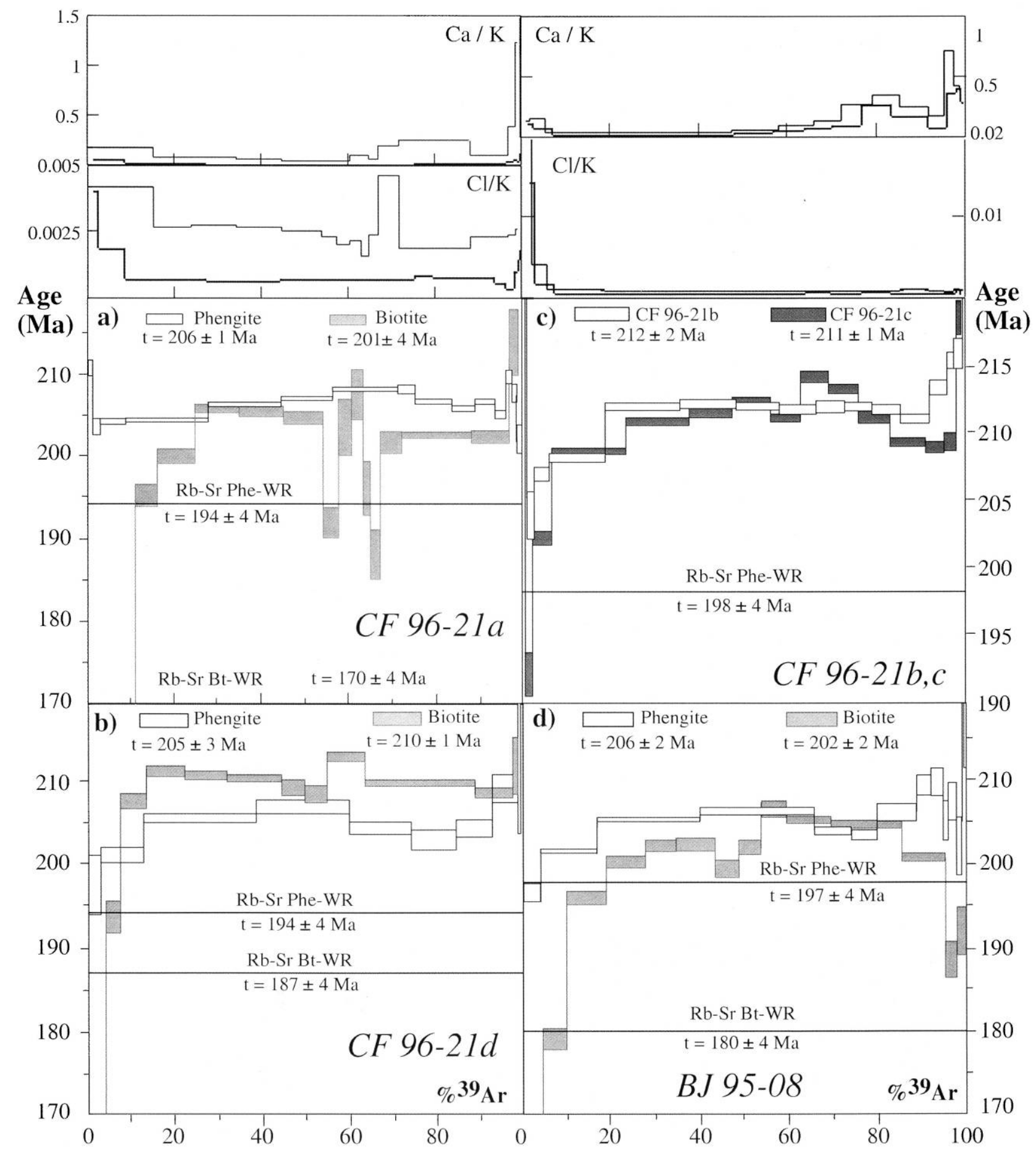

Figure 7. $a-d$, Ar-Ar age spectra of phengite and biotite from gneisses of the Bixiling Complex. Irregularities in the age spectra are attributed to the chemical heterogeneities that are recognized in figures 6 and 8 . The variation of $\mathrm{Cl} /$ $\mathrm{K}$ and $\mathrm{Ca} / \mathrm{K}$ ratios as a function of the percentage of ${ }^{39} \mathrm{Ar}$ released is also shown for samples CF 96-21a (thick line, phengite; thin line, biotite), CF 96-21b, and CF 96-21c. 
formed by anatexis of an older basement, probably in a volcanic arc setting. Furthermore, Hacker et al. (1998) suggested that $\mathrm{U}-\mathrm{Pb}$ zircon ages at $\sim 700$ $\mathrm{Ma}$ on various lithologies may reveal their affiliation to the Yangtze Craton.

At the Bixiling Complex, the UHPM event was previously dated at 210-220 Ma by seven Sm-Nd Grt-Omp-WR isochrons on coesite-bearing eclogites (Chavagnac and Jahn 1996) and by U-Pb measurements on eclogitic zircon (D. Liu, unpublished data). Our $\mathrm{U}-\mathrm{Pb}$ data on zircon from the country
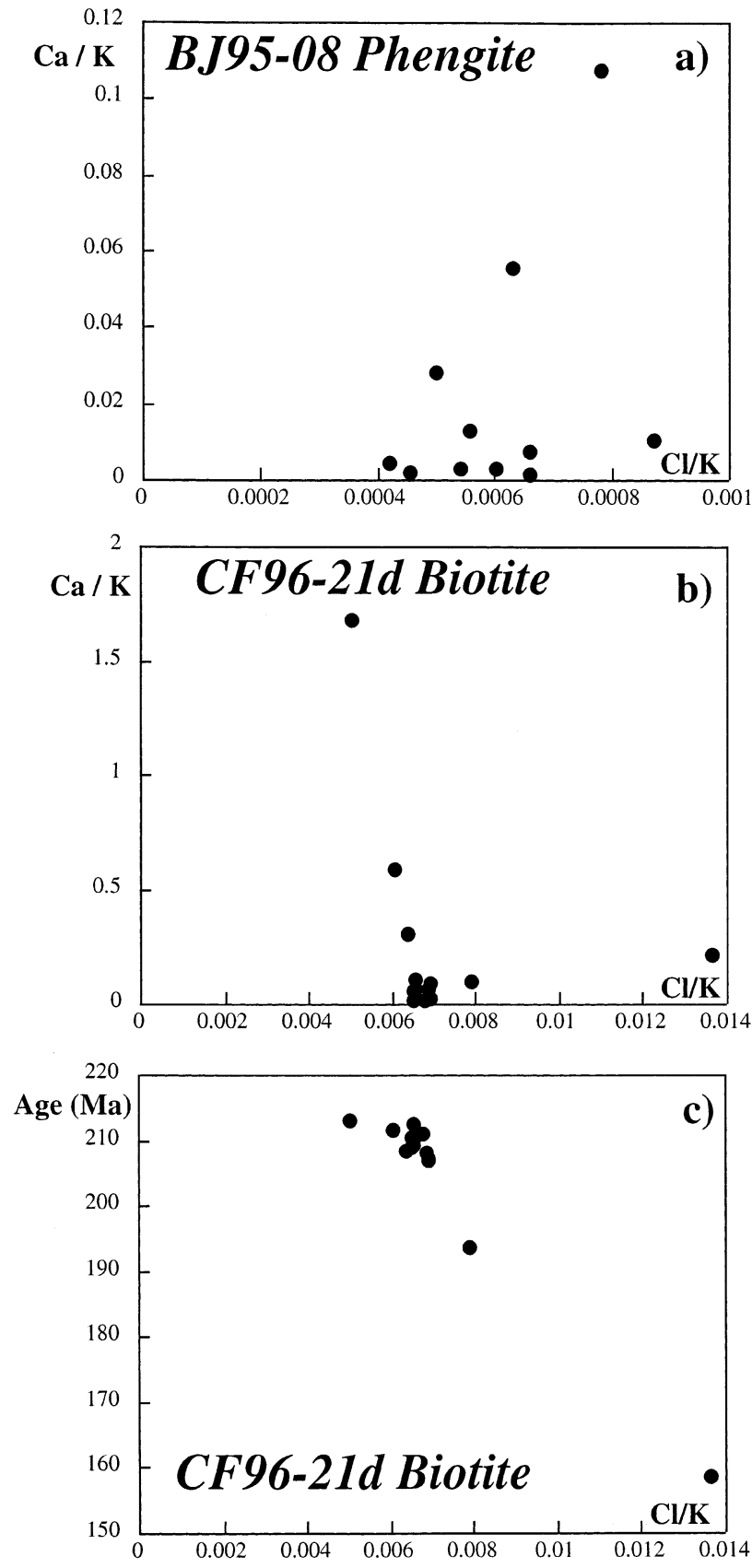

rock do not emphasize the Triassic UHPM age as did eclogitic zircons. Up to now, only zircons from the Shima and Wumiao eclogite host gneisses, which present extreme metamorphic conditions (pressure up to $41 \mathrm{kbars}$ ), recorded the 220-210-Ma event (Ames et al. 1993; Rowley et al. 1997; Xue et al. 1997; Hacker et al. 1998). The lack of a record of 220 -Ma ages in the gneissic zircons may simply be an artifact of sampling, or it may indicate the inability of zircons to accrete new rims during retrograde metamorphism due to a lack of suitable fluids. Further investigations using the U-Pb radiogenic system have to be performed on various accessory phases to solve that issue. Fortunately, our $\mathrm{Rb}-\mathrm{Sr}$ and Ar-Ar ages on Phe (194 \pm 4 to $212 \pm 2$ $\mathrm{Ma}$ ) strongly suggest that the country rocks also underwent a Triassic metamorphism, as did the eclogites. Their ages also overlap the previous $\mathrm{Rb}$ Sr Phe ages on coesite-bearing eclogites of the Bixiling Complex at $198 \pm 4$ to $223 \pm 13 \mathrm{Ma}$ (Chavagnac and Jahn 1996). Strictly speaking, the Rb-Sr dates on the host gneisses of the Bixiling Complex pertain to the Ab-Ep amphibolite facies. The essential point is that our geochronological data indicate a coeval metamorphic history of the eclogites and country gneisses and, therefore, support evidence for an in situ tectonic relationship between them.

The protolith age of the Shuanghe gneisses /CF

Figure 8. Three-isotope correlation diagrams. System atics and diagnostic capabilities of such diagrams are reviewed by Villa (2001). $a, \mathrm{Ca} / \mathrm{K}$ versus $\mathrm{Cl} / \mathrm{K}$ correlation for phengite BJ95-08, for which electron microprobe data reveal a remarkable compositional heterogeneity. The distribution of data points in a triangular field requires three distinct $\mathrm{Ar}$ reservoirs: one with $\mathrm{Ca} / \mathrm{K}<0.01, \mathrm{Cl} / \mathrm{K}=$ 0.0004; one with $\mathrm{Ca} / \mathrm{K}>0.1, \mathrm{Cl} / \mathrm{K} \geq 0.0007$; and one with $\mathrm{Ca} / \mathrm{K}=0.01, \mathrm{Cl} / \mathrm{K} \geq 0.0009$. The high-Ca reservoir is associated to small amounts of ${ }^{39} \mathrm{Ar}$ and represents alteration and/or impurity phases. The zoned phengite is likely to account for the low-Ca array with variable $\mathrm{Cl} / \mathrm{K}$. Complementary age information to $a$ is provided by the correlation of the chemical composition (here the $\mathrm{Cl} / \mathrm{K}$ ratio) with age (table 3 ; fig. 6). $b, \mathrm{Ca} / \mathrm{K}$ versus $\mathrm{Cl} / \mathrm{K}$ correlation diagram for biotite CF 96-21d. With the exception of minor Ca-rich and Cl-rich steps, its composition is much more homogeneous than that of phengites, as confirmed by electron microprobe analyses. $c$, age versus $\mathrm{Cl} / \mathrm{K}$ correlation for biotite CF 96-21d. The negative correlation is explained by the presence of minor secondary alteration phases with high $\mathrm{Cl}$ and low apparent ages; the reservoir with the highest $\mathrm{Ca} / \mathrm{K}$ and the highest step age must be attributed to a calcic contaminant. 
96-39) is poorly constrained since the U-Pb SIMS data points are discordant in the concordia diagram (fig. 3b). Nevertheless, the regression line yields an upper intercept of $\sim 2.5 \mathrm{Ga}$. This is in-line with negative $\epsilon_{\mathrm{Nd}}$ values related to Early Proterozoic to Late Archean Nd model ages (2.2-3.2 Ga; table 1) and previous U-Pb zircon data (Xue et al. 1997). The lower concordia intercept at $233 \pm 21 \mathrm{Ma}$ (fig. $3 b$, $3 c$ ) indicates that zircons have recorded the UHPM event. This is supported by the low $\mathrm{Th} / \mathrm{U}$ ratios of zircons $(\sim 0.02)$, which are typical for overgrowths during metamorphic overprints, and by a Sm-Nd Grt-Ky-WR isochron at $231 \pm 35 \mathrm{Ma}$ (MSWD = 2.89; fig. 4). Although the MSWD value is $>1$, the $\mathrm{Nd}$ isotopic compositions of Grt, Ky, and WR at 235 Ma cluster within $\pm 0.5 \epsilon_{\mathrm{Nd}}$, which confirms that full $\mathrm{Nd}$ isotope exchange was reached at that time. In addition, the Sm-Nd isochron is dominated by Grt, which presents a high $\mathrm{Sm} / \mathrm{Nd}$ ratio compared with WR and Ky (table 1); that is, the obtained age reveals the time of Grt crystallization during the eclogite facies metamorphism. The coesite-bearing eclogite, the Grt-bearing gneisses, the Ep-two mica gneiss, and the coesite-bearing jadeite quartzite are interlayered, and according to the detailed petro-metamorphic study of Zhang et al. (1995), Cong et al. (1995), and Liou et al. (1997), they shared the same clockwise PT path. Consequently, our multichronometric approach on CF 96-39 indicates that the peak eclogite facies metamorphism at Shuanghe is dated at $\sim 230 \mathrm{Ma}$.

In addition, Cong et al. (1995) argued that the UHPM rocks and their retrograde products (e.g., Grt-Bt gneiss) have an exotic/tectonic emplacement with the low-pressure quartzo-feldspathic gneisses. $T_{\mathrm{DM}}$ ages and also $\epsilon_{\mathrm{Nd}}(0)=-18.2$ of the UHPM rocks indicate an Archean origin while host gneisses are Proterozoic (Jahn et al. 1994), but it is uncertain when their juxtaposition took place. At present, it is still unclear whether or not Grt-Bt gneisses represent the retrograde metamorphic products of eclogites, and therefore, the in situ or foreign model remains controversial at Shuanghe.

Contrasting Ar-Ar and Rb-Sr Mineral Ages. At the Bixiling locality, Ar-Ar Phe and Bt ages of the country gneisses vary between 201 and $212 \mathrm{Ma}$, and they overlap the Sm-Nd and $\mathrm{Rb}-\mathrm{Sr}$ ages obtained on the coesite-bearing eclogites (Chavagnac and Jahn 1996). However, the Ar-Ar Phe and Bt ages are up to $15 \mathrm{Ma}$ older than the corresponding Rb-Sr Phe and Bt ages of the gneisses. One possible interpretation is the incorporation of excess Ar. Several studies on highpressure white micas indicated that Ar-Ar ages are geologically meaningless due to excess Ar (Tilton et al. 1991; Tonarini et al. 1993; Li et al. 1994; Arnaud and Kelley 1995; Hacker and Wang 1995). Li et al. (1994) and Boundy et al. (1997) suggested that excess $\mathrm{Ar}$ in Phe is mainly observed in Bt-free UHP-HP rocks. If this were the case, we would expect the Bixiling rocks to show exceedingly high Bt ages, as excess Ar is supposedly partitioned into Bt. Since this is not the case, we conclude that little or no excess Ar can be made responsible for the Ar-Ar versus $\mathrm{Rb}$-Sr age discrepancy, especially for the white mica, which are protected from excess Ar by the Bt according to the above-mentioned articles. The age difference must be interpreted in other ways; for example, it could indicate that several generations of mineral growth are present (meaning that the constituent minerals of a rock were never in mutual equilibrium at the same time) or that Ar and Sr components were inherited due to incomplete resetting of Ar-Ar and Rb-Sr clocks. Of special interest is the behavior of Sr during the amphibolite-facies hydration. Apatite and Ep, the main carriers of $\mathrm{Sr}$ in the present whole-rock system, may have inherited $\mathrm{Sr}$ from the UHP protolith by closed-system redistribution, while the white micas remained largely unaffected. The Rb-Sr age calculated from the Ap-Ep white mica thus may give an excessively low age.

We performed a detailed study of the Phe mineral chemistry and paragenetic relationship between samples and zonation within grains. The celadonite content of Phe is shown in terms of Tschermak's substitution $\left(\mathrm{MgSi}=\mathrm{Al}^{\mathrm{IV}} \mathrm{Al}{ }^{\mathrm{VI}}\right)$. Figure 6 illustrates the variability of Phe chemical composition from sample to sample and within grains. The inset in figure $6 b$ represents the variation of Tschermak's substitution along a cross section through one Phe grain (sample BJ 95-08). Some important observations are (1) the association of different generations of Phe (as illustrated by one example of Si profile), (2) the celadonitic reequilibration of Phe through retrograde metamorphism, and (3) the higher $X_{\mathrm{Mg}}$ content for Phe of Bt-free gneisses (fig. 6b). Sample BJ 95-08 has preserved a HP Phe phase $(\mathrm{Si}=3.4$ a.p.f.u.), and a new generation of Phe had crystallized during the retrograde metamorphism. Phe from the four other samples (collected in the field a little farther from BJ 95-08) exhibits partial chemical reequilibration as highlighted by the continuous decrease of the Si content from 3.35 to 3.21 a.p.f.u. (mean at $\sim 3.31$ a.p.f.u.). Using Massonne and Schreyer's (1987) Phe geobarometer, we conclude that the country rock of the Bixiling Complex underwent rapid decompression from eclogite facies $\left(\mathrm{Si}=3.4\right.$ a.p.f.u.; $P \approx 13-12$ kbar; $\left.T \approx 600^{\circ} \mathrm{C}\right)$ toward Ab-Ep amphibolite facies (mean $\mathrm{Si}=3.31$ a.p.f.u.; $P \approx 8-7$ kbar; $T<600^{\circ} \mathrm{C}$ ), which indicates that the coesite-bearing eclogites and their gneissic 
surroundings shared a coeval metamorphism from eclogite facies to lower PT conditions during which partial chemical reequilibration took place.

Deducing the in vacuo sequential degassing of different generations of Phe or a mixture of Phe and tiny inclusions from Ar-Ar age spectrum requires a careful diagnosis and identification, as was pointed out in a study of amphibole by Belluso et al. (2000). This may be done by using three-isotope correlation diagrams $\left({ }^{37} \mathrm{Ar},{ }^{38} \mathrm{Ar}\right.$, and $\left.{ }^{39} \mathrm{Ar}\right)$ referred to as $\mathrm{Cl} / \mathrm{Ca} /$ $\mathrm{K}$ plots. The $\mathrm{Cl} / \mathrm{K}$ ratios for all Phe samples cluster at about 0.0005 , while the $\mathrm{Ca} / \mathrm{K}$ ratios vary (table 3 ). In figure 8 , we plotted the variation of the $\mathrm{Cl} / \mathrm{K}$ ratios as a function of $\mathrm{Ca} / \mathrm{K}$ or age for specific samples $\mathrm{BJ} 95$ 08 phengite and CF 96-21d biotite. For the Bt-bearing gneisses, namely CF 96-21a, CF 96-21d, and BJ 9508 , most of the Phe yielded similar ages of $\sim 206 \mathrm{Ma}$ for the main ${ }^{39} \mathrm{Ar}$ gas release (steps with $\mathrm{Ca} / \mathrm{K}$ ratios $<0.04$ ), whereas high-temperature steps were characterized by higher $\mathrm{Ca} / \mathrm{K}$ ratios without significant variation in age. In contrast, Phe of the Bt-free gneisses CF 96-21b and CF 96-21c presented highly variable $\mathrm{Ca} / \mathrm{K}$ ratios related to older age $(\sim 210 \mathrm{Ma})$, and $20 \%$ of the ${ }^{39} \mathrm{Ar}$ release corresponded to $\mathrm{Ca} / \mathrm{K}$ ratios $>0.1$. Therefore, these observations suggest the presence of minute inclusions of a Ca-bearing mineral in the Phe. The mineral paragenesis observed is related to the Ab-Ep amphibolite facies, and under these conditions, the stable Ca mineral is Ep (Nagasaki and Enami 1998). In the case of the Btbearing gneisses, this reveals the influence of a minute admixture of Ep on the Ar gas release at hightemperature steps (cf. Villa et al. 1996). Moreover, the shape of the age spectra reflects the differential degassing rates of the different white-mica generations (Villa et al. 1997). For the Bt-free gneisses, a significant proportion of ${ }^{39} \mathrm{Ar}$ releases comes from a Ca-bearing phase. However, the hump-shaped Ar-Ar spectra of Phe CF 96-21c give an age at $211 \pm 2 \mathrm{Ma}$, which is in-line with the flat Ar-Ar age spectra of Phe CF 96-21b at $212 \pm 2 \mathrm{Ma}$. This suggests that Ep, which certainly represents the Ca-bearing phase, is cogenetic with the high-pressure mineral paragenesis. The influence of the minute occurrence of Ep within Phe and the cogenetic crystallization of Ep with intermediate-pressure Phe $(\mathrm{Si}=3.2-3.3$ a.p.f.u.) are also supported by the five $\mathrm{Rb}-\mathrm{Sr}$ Phe isochrons that give indistinguishable ages with low MSWD (0.04-0.28) and also by their intimate association in thin section. In addition, figure 5 shows the Ar-Ar phengite age as a reference line for each sample. These reference lines all correspond to an initial Sr isotopic composition that is slightly but significantly less radiogenic than the intercept of the $\mathrm{Rb}-\mathrm{Sr}$ regression through Phe-Ep-WR(-Ap), espe- cially in Bt-free gneisses. This may indicate that Ep and Ap (which crystallized during hydration under Ab-Ep amphibolite facies) incorporated more radiogenic Sr than that present at the time of crystallization of the white mica. The noncogenetic minerals Phe and Ep were not isotopically equilibrated.

To interpret the Ar-Ar Bt ages, it can be useful to take chemical information into account. The Bt samples that were analyzed for Ar-Ar and Rb-Sr dating have $\mathrm{K}_{2} \mathrm{O}$ contents of 4-5 wt \%, which is significantly lower than the stoichiometric $\mathrm{K}_{2} \mathrm{O}$ concentrations of $\sim 9.5 \mathrm{wt} \%$. The $\mathrm{Ca} / \mathrm{K}$ ratios of $\mathrm{Bt}$ /table 3 ) do not vary from sample to sample; the $\mathrm{Cl} / \mathrm{K}$ ratios are nearly constant within one sample, but they are distinguishable between samples. The degree of alteration (monitored via the $\mathrm{K}$ concentrations and the $\mathrm{Cl} / \mathrm{K}$ ratio) correlates with the $\mathrm{Ar}-\mathrm{Ar}$ and $\mathrm{Rb}-\mathrm{Sr}$ ages as shown by biotite CF 96-21d, which is the least altered and yields the oldest $\mathrm{Ar}-\mathrm{Ar}$ and $\mathrm{Rb}-\mathrm{Sr}$ ages (210 \pm 1 and $187 \pm 4 \mathrm{Ma}$, respectively). Retrograde metamorphism is related to fluid circulation, as highlighted by the transformation of coesite-bearing eclogite into amphibolite along fractures and by the alteration of Bt. However, the preservation of unusually low $\delta^{18} \mathrm{O}$ in both eclogites and gneisses argues against a regional-scale infiltration of fluid during the entire process of subduction and exhumation (Yui et al. 1995, 1997; Baker et al. 1997; Zheng et al. 1998; Fu et al. 1999|. Preliminary oxygen isotope results on the coesite-bearing eclogites of the Bixiling Complex indicate that the basaltic protolith underwent regional-scale meteoric hydrothermal alteration but that this happened before the UHPM event (Baker et al. 1997). Baker et al. (1997) concluded that the retrograde metamorphism is not associated with a significant fluid volume on a regional scale. However, the hydrated paragenesis clearly shows that hydrous fluid did circulate; the only constraint coming from oxygen isotope measurements is that these fluids did not have an external origin.

\section{Conclusions}

In this study, a multichronometric approach was used to tackle the problem of eclogite-gneiss tectonic relationship during the UHPM event. The following conclusions were reached:

1. U-Pb zircon ages confirm that the protolith ages are Late Proterozoic at Bixiling ( 500-700 Ma) and Late Archean to Early Proterozoic at Shuanghe. These ages are in line with the Sm-Nd $T_{\mathrm{DM}}$ model ages.

2. On the gneisses of the Shuanghe sheet, the eclogite facies assemblage was dated at $\sim 230 \mathrm{Ma}$ by U- 
$\mathrm{Pb}$ zircon analyses, which is in agreement with a Sm-Nd Grt-Ky-WR isochron age at $231 \pm 35 \mathrm{Ma}$. On gneisses from the Bixiling locality, Rb-Sr and Ar-Ar Phe dating yields a narrow age range of 198-212 Ma, which overlaps the 190-220-Ma age given by Sm$\mathrm{Nd}$ and $\mathrm{Rb}-\mathrm{Sr}$ mineral isochrons on coesite-bearing eclogites (Chavagnac and Jahn 1996). The finding that the country rocks of coesite-bearing eclogites at Bixiling underwent a coeval metamorphic event with the eclogites supports an in situ tectonic relationship.

3. Electron microprobe analyses indicate the preservation of a HP phengite phase together with a younger white-mica generation crystallized during the retrograde metamorphism under Ab-Ep amphibolite facies. The irregularities in the Ar-Ar age spectra are explained as an effect of this observation and confirm the systematic predictions of Villa et al. (1997). The effect of excess ${ }^{40} \mathrm{Ar}$ is constrained to be small or negligible from the comparison with $\mathrm{Rb}-\mathrm{Sr}$ dating of the same mica separates.

\section{A C K N O W L E D G M E N T S}

V. Chavagnac and B.-m. Jahn are indebted to members of CAGS for their support during fieldwork in the Dabie Mountains. M. Ballèvre and J. Kramers are thanked for stimulating discussions, and the review by B. Hacker is gratefully acknowledged. We acknowledge support for the electron microprobe of the University of Bern by the Swiss National Foundation (SNF; grant 21-26579.89) and support by the SNF (grant 20-47157.96) to J. Kramers. The Nordsim ion microprobe in Stockholm is supported by the research funding agencies of Denmark, Finland, Norway, and Sweden; M. Whitehouse acknowledges the support of the Swedish National Foundation for Research. This is Nordsim laboratory contribution 20 .

\section{R E F E R E N C E S C I T E D}

Ames, L. 1995. Geochronology and Isotopic character of ultrahigh-pressure metamorphism with implications for collision of the Sino-Korean and Yangtze Cratons, Central China. Ph.D. dissertation, University of California, Santa Barbara.

Ames, L.; Tilton, G. R.; and Zhou, G. 1993. Timing of collision of the Sino-Korean and Yangtze Cratons: U$\mathrm{Pb}$ zircon dating of coesite-bearing eclogites. Geology 21:339-342.

Arnaud, N. O., and Kelley, S. P. 1995. Evidence for excess argon during high pressure metamorphism in the Dora Maira Massif (western Alps, Italy), using an ultra-violet laser ablation microprobe ${ }^{40} \mathrm{Ar}^{39} \mathrm{Ar}$ technique. Contrib. Mineral. Petrol. 121:1-11.

Baker, J.; Mattews, A.; Mattey, D.; Rowley, D.; and Xue, F. 1997. Fluid-rock interactions during ultrahigh pressure metamorphism, Dabies Shan, China. Geochim. Cosmochim. Acta 61:1685-1696.

Belluso, E.; Ruffini, R.; Schaller, M.; and Villa, I. M. 2000. Electron-microscope and Ar isotopic characterization of chemically heterogeneous amphiboles from the Palala Shear Zone, Limpopo Belt, South Africa. Eur. I. Mineral. 12:45-62.

Boundy, T. M.; Hall, C. M.; Li, G.; Essene, E. J.; and Halliday, A. N. 1997. Fine-scale isotopic heterogeneities and fluids in the deep crust: $\mathrm{a}^{39} \mathrm{Ar} /{ }^{40} \mathrm{Ar}$ laser ablation and TEM study of muscovites from a granulite-eclogite transition zone. Earth Planet. Sci. Lett. 148:223-242.

Chavagnac, V. 1998. Behaviour of the Sm-Nd system during metamorphism: examples from the HT-LP metamorphic terrane (The Limpopo Belt, South Africa) and the UHP metamorphic terrane (The Dabie Shan,
China). Ph.D. thesis. University of Rennes 1 and University of Bern.

Chavagnac, V., and Jahn, B.-m. 1996. Coesite-bearing eclogites from the Bixiling Complex, Dabie Mountains, China: $\mathrm{Sm}-\mathrm{Nd}$ ages, geochemical characteristics and tectonic implications. Chem. Geol. 133:29-51.

Chavagnac, V.; Nägler, T. F.; and Kramers, J. D. 1999. Migmatization by metamorphic segregation at subsolidus conditions: implications for $\mathrm{Nd}-\mathrm{Pb}$ isotope exchange. Lithos 46:275-298.

Cong, B.; Zhai, M.; Carswell, D. A.; Wilson, R. N.; Wang, Q.; Zhao, Z.; and Windley, B. F. 1995. Petrogenesis of ultrahigh-pressure rocks and their country rocks at Shuanghe in Dabieshan, Central China. Eur. I. Mineral. 7:119-138.

Enami, M., and Zhang, Q. 1990. Quartz pseudomorph after coesite in eclogites from Shandong province, east China. Am. Mineral. 75:381-386.

Fu, B.; Zheng, Y.-F.; Wang, Z.; Xiao, Y.; Gong, B.; and Li, S. 1999. Oxygen and hydrogen isotope geochemistry of gneisses associated with ultrahigh pressure eclogites at Shuanghe in the Dabie Mountains. Contrib. Mineral. Petrol. 134:52-66.

Goldstein, S. L.; O'Nions, R. K.; and Hamilton, P. J. 1984. A Sm-Nd isotopic study of atmospheric dusts and particulates from major river systems. Earth Planet. Sci. Lett. 70:221-236.

Hacker, B. R.; Ratschbacher, L.; Webb, L.; Ireland, T.; Walker, D.; and Shuwen, D. 1998. U/Pb zircon ages constrain the architecture of the ultrahigh-pressure Qinling-Dabie orogen, China. Earth Planet. Sci. Lett. 161:215-230.

Hacker, B. R., and Wang, Q. C. 1995. Ar/Ar geochronol- 
ogy of ultrahigh-pressure metamorphism in central China. Tectonics 14:994-1006.

Hirajima, T.; Ishiwatari, A.; Cong, B.; Zhang, R.; Banno, S.; and Nozaka, T. 1990. Coesite from Mengzhong eclogite at Donghai country, northeastern Jiangsu province, China. Mineral. Mag. 54:579-583.

Jahn, B.-m. 1998. Geochemical and isotopic characteristics of UHP eclogites and ultramafic rocks of the Dabie orogen: implications for continental subduction and collisional tectonics. In Hacker, B., and Liou, J. G., eds. When continents collide: geodynamics and geochemistry of ultrahigh pressure rocks. Dordrecht, Kluwer, p. 203-239.

Jahn, B.-m.; Cornichet, J.; Henin, O.; Le Coz Bouhnik, M.; and Cong, B. L. 1994. Geochemical and isotopic investigation of ultrahigh pressure (UHP) metamorphic terranes in China: Su-Lu and Dabie complexes. Standford Workshop on Ultrahigh Pressure Metamorphism and Tectonics, p. A71-A74.

Li, S.; Jagoutz, E.; Chen, Y.; and Li, Q. 2000. Sm-Nd and $\mathrm{Rb}-\mathrm{Sr}$ isotopic chronology and cooling history of ultrahigh pressure metamorphic rocks and their country rocks at Shuanghe in the Dabie Mountains, Central China. Geochim. Cosmochim. Acta 64:1077-1093.

Li, S.; Wang, Y. C.; Liu, D.; Zhou, H.; and Zhang, Z. 1994. Excess argon in phengite from eclogite: evidence from dating of eclogite minerals by $\mathrm{Sm}-\mathrm{Nd}, \mathrm{Rb}-\mathrm{Sr}$ and ${ }^{40} \mathrm{Ar} /$ ${ }^{39}$ Ar methods. Chem. Geol. 112:343-350.

Li, S.; Xiao, Y.; Liou, D.; and Chen, Y. 1993. Collision of the North China and Yangtze blocks and formation of coesite-bearing eclogites: timing and processes. Chem. Geol. 109:89-111.

Liou, J. G.; Zhang, R. Y.; and Ernst, W. G. 1995. Occurrences of hydrous and carbonate phases in ultrahighpressure rocks from east-central China: implications for the role of volatiles deep in cold subduction zones. Island Arc 4:362-375.

Liou, J. G.; Zhang, R. Y.; and Jahn, B.-m. 1997. Petrology, geochemistry and isotope data on a ultrahigh pressure jadeite quartzite from Shuanghe, Dabie Mountains, East-Central China. Lithos 41:59-78.

Ludwig, K. R. 1999. User's manual for isoplot/Ex. Version 2.2. A geochronological toolkit for Microsoft Excel. Berkeley Geochronology Center Spec. Pub. 1a, 53 p.

Maruyama, S.; Liou, J. G.; and Zhang, R. 1995. Tectonic evolution of the ultrahigh-pressure (UHP) and highpressure (HP) metamorphic belts from central China. Island Arc 3:112-121.

Massonne, H.-J., and Schreyer, W. 1987. Phengite geobarometry based on the limiting assemblage with Kfeldspar, phlogopite, and quartz. Contrib. Mineral. Petrol. 96:212-224.

Nagasaki, A., and Enami, M. 1998. Sr-bearing zoïsite and epidote in ultrahigh pressure (UHP) metamorphic rocks from the Su-Lu province, eastern China: an important Sr reservoir under UHP condition. Am. Mineral. 83:240-247.

Okay, A. I. 1993. Petrology of diamond and coesite-bearing metamorphic terrain: Dabie-Shan, China. Eur. I. Mineral. 5:659-675.
Okay, A. I., and Sengör, A. M. C. 1992. Evidence for intracontinental thrust-related exhumation of the ultrahigh-pressure rocks in China. Geology 20:411-414.

Rowley, D. B.; Xue, F.; Tucker, R. D.; Peng, Z. X.; Baker, J.; and Davis, A. 1997. Ages of ultrahigh pressure metamorphism and protolith orthogneisses from the eastern Dabie Shan: U/Pb zircon geochronology. Earth Planet. Sci. Lett. 151:191-203.

Stacey, J. S., and Kramers, J. D. 1975. Approximation of terrestrial lead isotope evolution by a two-stage model. Earth Planet. Sci. Lett. 26:207-221.

Tilton, G. R.; Schreyer, W.; and Schertl, H. P. 1991. PbSr-Nd isotopic behavior of deeply subducted crustal rocks from the Dora Maira Massif, western Alps, Italy. II. What is the age of the ultrahigh-pressure metamorphism? Contrib. Mineral. Petrol. 108:22-33.

Tonarini, S.; Villa, I. M.; Oberli, F.; Meier, M.; Spencer, D. A.; Pognante, U.; and Ramsay, J. G. 1993. Eocene age of eclogite metamorphism in Pakistan Himalaya: implications for India-Eurasia collision. Terra Nova 5: 13-20.

Villa, I. M. 2001. Radiogenic isotopes in fluid inclusions. Lithos 55:115-124.

Villa, I. M.; Grobéty, B.; Kelley, S. P.; Trigila, R.; and Wieler, R. 1996. Assessing Ar transport paths and mechanisms in the McClure Mountains hornblende. Contrib. Mineral. Petrol. 126:67-80.

Villa, I. M.; Ruggieri, G.; and Puxeddu, M. 1997. Petrological and geochronological discrimination of two whitemica generations in a granite cored from LarderelloTravale geothermal field (Italy). Eur. I. Mineral. 9: 563-568.

Wang, X., and Liou, J. G. 1991. Regional ultrahigh-pressure coesite-bearing eclogitic terrane in central China: evidence from country rocks, gneiss, marble, and metapelites. Geology 19:933-936.

- 1993. Coesite-bearing eclogites from the Dabie Mountains in central China. Geology 17:1085-1088.

Wang, X.; Liou, J. G.; and Mao, H. K. 1989. Coesite-bearing eclogite from the Dabie Mountains in central China. Geology 17:1085-1088.

Wang, X.; Liou, J. G.; and Maruyama, S. 1992. Coesitebearing eclogite from the Dabie Mountains, Central China: petrogenesis, PT paths and implications for regional tectonics. I. Geol. 100:231-250.

Whitehouse, M. J.; Claesson, S.; Sunde, T.; and Vestin, J. 1997. Ion microprobe $\mathrm{U}-\mathrm{Pb}$ zircon geochronology and correlation of Archean gneisses from the Lewisian Complex of Guinard Bay, northwestern Scotland. Geochim. Cosmochim. Acta 61:4429-4438.

Whitehouse, M. J.; Kamber, B. S.; and Moorbath, S. 1999. Age significance of U-Th-Pb zircon data from Early Archean rocks of west Greenland: a reassessment based on combined ion-microprobe and imaging studies. Chem. Geol. 160:201-224.

Xu, J.; Zhu, G.; Tong, W.; Cui, K.; and Liu, Q. 1987. Formation and evolution of the Tangcheng-Lujiang wrench fault system: a major shear system to the northwest of the Pacific Ocean. Tectonophysics 134:273-310.

Xu, S.; Okay, A. I.; Ji, S.; Sengör, M. C.; Su, W.; Liu, Y.; 
and Jiang, L. 1992. Diamond from the Dabie Shan metamorphic rocks and its implication for tectonic setting. Science 256:80-83.

Xue, F.; Rowley, D. B.; Tucker, R. D.; and Peng, Z. H. 1997. U-Pb zircon ages of granitoid rocks in the north Dabie Complex, eastern Dabie Shan, China. I. Geol. 105:744-753.

Yang, J., and Smith, D. C. 1989. Evidence for a former sanidine-coesite-eclogite at Lanshantou, east China, and the recognition of the Chinese Su-Lu coesite eclogite province. 3d Intl. Eclogite Conf. Terra Abstr. 1:26.

Yin, A., and Nie, S. 1993. An indentation model for the north and south China collision and the development of the Tan-Lu and Homan fault systems, eastern China. Tectonics 12:801-813.

Yui, T.-F.; Rumble, D., III; Chen, C.-H.; and Lo, C.-H.
1997. Stable isotope characteristics of eclogites from the ultra-high-pressure metamorphic terrain, eastcentral China. Chem. Geol. 137:135-147.

Yui, T.-F.; Rumble, D., III; and Lo, C.-H. 1995. Unusually low $\partial^{18} \mathrm{O}$ ultra-high-pressure metamorphic rocks from the Su-Lu terrain, eastern China. Geochim. Cosmochim. Acta 59:2859-2864.

Zhang, R. Y.; Liou, J. G.; and Cong, B. L. 1995. Talc, magnesite and Ti-clinohumite-bearing UHP metamafic and ultramafic complex in the Dabie Mountains, China. I. Petrol. 36:1011-1037.

Zheng, Y. F.; Fu, B.; Li, Y.; Xiao, Y.; and Li, S. 1998. Oxygen and hydrogen isotope geochemistry of ultrahigh pressure eclogites from the Dabie Mountains and the Sulu terrane. Earth Planet. Sci. Lett. 155:113-129. 